\title{
Riboflavin deficiency in the rat: effects on iron utilization and loss
}

\author{
BY HILARY J. POWERS*, L. T. WEAVER AND S. AUSTIN \\ MRC Dunn Nutrition Unit, Milton Road, Cambridge CB4 IXJ \\ AND A. J. A. WRIGHT AND SUSAN J. FAIRWEATHER-TAIT \\ AFRC Institute of Food Research, Norwich Laboratory, Colney Lane, Norwich NR4 7UA
}

(Received 23 April 1990 - Accepted 18 October 1990)

\begin{abstract}
Iron absorption and daily loss of $\mathrm{Fe}$ were measured in riboflavin-deficient $\left(\mathrm{B}_{2}^{-}\right)$Norwegian hooded rats and controls $\left(\mathrm{B}_{2}^{+}\right)$. Animals were fed on a test meal extrinsically labelled with ${ }^{59} \mathrm{Fe}$ and whole-body radioactivity measured for $15 \mathrm{~d}$. Riboflavin deficiency led to a reduction in the percentage of the ${ }^{59} \mathrm{Fe}$ dose absorbed and an increased rate of ${ }^{59} \mathrm{Fe}$ loss. All post-absorption ${ }^{59} \mathrm{Fe}$ loss could be accounted for by faecal ${ }^{59} \mathrm{Fe}$, confirming that the loss was gastrointestinal. Fe concentrations and ${ }^{59} \mathrm{Fe}$ as a percentage of retained whole-body ${ }^{59} \mathrm{Fe}$ were higher in the small intestine of riboflavin-deficient animals than their controls, $14 \mathrm{~d}$ after the test meal. A separate experiment demonstrated that riboflavin deficiency was associated with a significant proliferative response of the duodenal crypts of the small intestine. These observations may explain the enhanced Fe loss in riboflavin deficiency.
\end{abstract}

Riboflavin: Iron: Crypt cell proliferation: Rat

There is considerable evidence from studies in both animals and humans that poor riboflavin status can disturb iron economy (Buzina et al. 1979; Powers et al. 1983a, b; Adelekan \& Thurnham, 1986). It seems as though riboflavin may be important at several stages of Fe utilization including mobilization of Fe from stores, and absorption (Sirivech et al. 1977; Powers, 1986; Powers et al. 1988). Attempts to elucidate the mechanisms of this involvement have concentrated on the effects of riboflavin deficiency on the activity of a flavin-dependent oxidoreductase (ferriductase) system which can, at least in vitro, release Fe from ferritin (Zaman \& Verwilghen, 1977; Ulvik \& Romslo, 1981; Powers et al. 1983a). A previous study investigated the effects of riboflavin deficiency on Fe absorption in vivo in rats and demonstrated very clearly that not only was Fe absorption impaired, but also that daily Fe loss was increased (Powers et al. 1988). We have repeated and extended this earlier study to try and provide some further insight into the mechanism of the effect of riboflavin deficiency on Fe metabolism.

\section{MATERIALS AND METHODS \\ Fe utilization study}

Seventy female Norwegian hooded 5-week-old weanling rats $(90-130 \mathrm{~g})$ were fed on a basal diet containing $(\mathrm{g} / \mathrm{kg}$ ) arachis oil 30 , sucrose 700 , casein 200 (supplying $0.52 \mathrm{mg}$ riboflavin (vitamin $\mathrm{B}_{2}$ ) $/ \mathrm{kg}$ diet) and a vitamin and salt mixture (Powers, 1987). Rats were allocated

* Present address: University of Sheffield, Department of Paediatrics, Clinical Sciences Centre, Northern General Hospital, Sheffield S5 7AU. 
to one of two dietary groups, one group to receive the basal diet (treatment $\mathrm{B}_{2}{ }^{-}$) and the other group to receive the basal diet with an additional $15 \mathrm{mg}$ riboflavin $/ \mathrm{kg}$ diet (treatment $\mathrm{B}_{2}{ }^{+}$). For 2 weeks, treatment $\mathrm{B}_{2}{ }^{-}$animals were fed ad lib. Treatment $\mathrm{B}_{2}{ }^{+}$animals were paired by weight to treatment $\mathbf{B}_{2}^{-}$animals. The food intake of each control (treatment $\mathrm{B}_{2}{ }^{+}$) animal was adjusted daily in order to maintain a similar growth rate to that of its treatment $B_{2}$ counterpart. For the following 3 weeks animals were trained to meal feed so that a $1 \mathrm{~d}$ food allowance was consumed within a $2 \mathrm{~h}$ period during the morning; treatment $\mathrm{B}_{2}{ }^{+}$animals again had their intakes restricted to maintain the weight of their treatment $\mathrm{B}_{2}^{-}$partner. All animals were then given a fixed amount $(12 \mathrm{~g})$ of their diet each morning for $3 \mathrm{~d}$ in order to standardize Fe intakes, since dietary Fe intake can influence subsequent Fe absorption from a test meal (Fairweather-Tait \& Wright, 1984); the result of a short-term mucosal effect which can last for up to $3 \mathrm{~d}$ after any dietary change (Fairweather-Tait et al. 1985). Following a $22 \mathrm{~h}$ fast, each animal was given a test meal of $3 \mathrm{~g}$ of a cooked starch-sucrose $(1: 1, \mathrm{w} / \mathrm{w})$ paste containing $120 \mu \mathrm{g} \mathrm{Fe}$ (as ferrous sulphate in $0 \cdot 1 \mathrm{M}$-hydrochloric acid) extrinsically labelled with $37 \mathrm{kBq}{ }^{59} \mathrm{Fe}$ (ferric chloride in $0 \cdot 1 \mathrm{M}-\mathrm{HCl}, 110-740 \mathrm{MBq} / \mathrm{mg} \mathrm{Fe}$; Amersham International Plc, Amersham, Bucks.). At $5 \mathrm{~h}$ after finishing the test meal all animals were given $12 \mathrm{~g}$ of their respective diets and were maintained at $12 \mathrm{~g}$ food $/ \mathrm{d}$ for the duration of the experiment.

Each rat was placed in a small-animal, whole-body gamma-counter (NE 8112; NE Technology, Beenham, Berks.) immediately after consuming the test meal (designated day 0 ) as previously described (Powers et al. 1988), to establish the exact initial ${ }^{54} \mathrm{Fe}$ dose. All rats consumed at least three-quarters of the test meal within $1 \mathrm{~h}$ and none was excluded from the experiment. Fifteen rats from each group killed after $7 \mathrm{~d}$ had an initial and day 7 count only, whereas twenty rats from each group killed after $14 \mathrm{~d}$ were counted daily. These latter forty rats also had their faecal output collected daily, starting immediately after the day 5 whole-body count, and this was monitored for ${ }^{59} \mathrm{Fe}$ in a Phillips PW 4580 automatic gamma-counter. True $\mathrm{Fe}$ absorption and the daily rate of $\mathrm{Fe}$ loss were calculated for the rats counted daily, as follows: for each rat, the $\log _{10}{ }^{59} \mathrm{Fe}$ retention (as $\%$ dose) ( $Y$ axis) for days 8-14 inclusive ( $X$ axis) were subjected to regression analysis to predict (a) the true ${ }^{59} \mathrm{Fe}$ absorption (antilog $\log _{10} Y$-axis intercept) and (b) the percentage rate of ${ }^{59} \mathrm{Fe}$ loss per $\mathrm{d}$ $\left(100\left(1-\operatorname{antilog}_{10}\right.\right.$ slope $\left.)\right)$.

On day 7 after receiving the test meal fifteen animals from each dietary group were weighed and killed by exsanguination under anaesthesia. Liver and small intestine (SI) were removed and washed in isotonic saline $(9 \mathrm{~g}$ sodium chloride/1). Samples of blood $(1 \mathrm{ml})$, liver and duodenum (proximal 10\% SI), ileum (distal $50 \% \mathrm{SI}$ ) and jejunum (remainder of SI) were monitored for ${ }^{59} \mathrm{Fe}$ in the Phillips automatic gamma-counter. The liver and sections of SI were then kept frozen until an estimation of total Fe content could be performed. Riboflavin status of the rats on the day before receiving the test meal and at the time of death was determined by measuring blood glutathione reductase (NAD(P)H) (EC 1.6.4.2) activation coefficient (BGRAC) (Powers et al. 1983a). Packed cell volume was measured in blood samples at the time of death of the animals.

On day 14 after receiving the test meal the remaining twenty rats from each group were killed in a similar manner to those killed on day 7 . All livers were freeze-dried, weighed and crushed to a homogeneous powder. Sections of SI were oven-dried for $16 \mathrm{~h}$ at $85^{\circ}$ for determination of dry weight. Each dried section of SI and a small sub-sample from each powdered liver were then ashed in a muffle furnace for $48 \mathrm{~h}$ at $480^{\circ}$, dissolved in a minimum volume of $11.7 \mathrm{M}-\mathrm{HCl}$ and further diluted with distilled water. The $\mathrm{Fe}$ content was determined by atomic absorption spectroscopy using a PU9000 (Pye Unicam, Cambridge). 


\section{Crypt cell study}

Six female Norwegian hooded rats were fed on a riboflavin-deficient diet (initially ad lib.) as described, from weaning $(21 \mathrm{~d})$ for 5 weeks. A further six animals receiving the complete diet were weight-matched to their riboflavin-deficient partners. Meal feeding was introduced after 2 weeks on the diets. After a $22 \mathrm{~h}$ fast, crypt cell proliferation was measured in the upper part of the SI of each animal using a stathmokinetic method.

The metaphase arrest agent, vincristine, was administered intraperitioneally $(1 \mathrm{mg} / \mathrm{kg})$ at time zero. Animals were killed by diethyl ether anaesthesia and cervical dislocation $150 \mathrm{~min}$ later. The abdomen was opened and the entire SI from pylorus to caecum removed. Its length was measured and a duodenal segment excised, at $50 \mathrm{~mm}$ distal to the pylorus.

Duodenal specimens were opened longitudinally and placed mucosal side uppermost on cards, fixed in Clarke's solution (ethanol-acetic acid $(75: 25, \mathrm{v} / \mathrm{v})$ ) for $24 \mathrm{~h}$ and stored in ethanol $(750 \mathrm{ml} / \mathrm{l})$ until staining. Specimens were bulk-stained by the Feulgen reaction: each was hydrated through descending concentrations of ethanol and hydrolysed in $1 \mathrm{M}$ $\mathrm{HCl}$ at $60^{\circ}$ for $5.5 \mathrm{~min}$ before staining with Schiff reagent for $35 \mathrm{~min}$. Under a stereomicroscope the serosal and muscle layers were removed and individual villus-crypt units microdissected. The depths and widths of ten well-orientated intact crypts were measured with an eyepiece micrometer. The tissue was then gently squashed under a cover slip in acetic acid $(450 \mathrm{ml} / 1)$ and the number of metaphase arrest figures per crypt counted. A mitotic index was calculated as the mean number of metaphase arrest figures per ten crypts per animal. This method of measuring crypt cell proliferation has been well validated (Wright \& Appleton, 1980; Wright \& Irwin, 1982).

The riboflavin status of the animals was determined by measuring BGRAC.

\section{Statistical methods}

Fe utilization study. BGRAC and body-weights, SI length, true ${ }^{59} \mathrm{Fe}$ retention, percentage rate of loss of absorbed ${ }^{59} \mathrm{Fe}$ per $\mathrm{d}$ and loss of initially-retained ${ }^{59} \mathrm{Fe}$ over $5-14 \mathrm{~d}$ accounted for in faecal output were compared by Student's unpaired $t$ test. Tissue Fe, specific activity of ${ }^{59} \mathrm{Fe},{ }^{59} \mathrm{Fe}$ either as percentage dose or percentage total ${ }^{59} \mathrm{Fe}$ retained at day of kill, and tissue dry weights, were subjected to two-way analysis of variance with the variables diet and time.

Crypt cell study. SI length, crypt depth and width, and mitotic index were compared using the Student's unpaired $t$ test.

\section{RESULTS}

\section{Fe utilization study}

Table 1 shows the mean body-weights of the rats at the time of dosing and the time of killing. Deficient $\left(\mathrm{B}_{2}^{-}\right)$animals killed $14 \mathrm{~d}$ after the dose were lighter than their controls $\left(\mathbf{B}_{2}^{+}\right)$.

BGRAC values $\geqslant 1.30$ are considered to indicate biochemical ariboflavinosis. Rats fed on the riboflavin-deficient diet (treatment $\mathrm{B}_{2}{ }^{-}$) were evidently deficient at the time of dosing and remained so for the duration of the experiment (Table 2). Rats fed on the control diet (treatment $\mathrm{B}_{2}^{+}$) had BGRAC values significantly lower than those of the depleted $\left(\mathrm{B}_{2}^{-}\right)$ group although some rats had values $>1.30$ (Table 2). In our experience, rats that are weight-matched or paired-fed with treatment $B_{2}^{-}$rats do sometimes show a BGRAC greater than 1.30 despite having tissue flavin concentrations indicative of adequate riboflavin status (Powers et al. 1983 a; Duerden \& Bates, 1985; Powers, 1986).

The percentage of the ${ }^{59} \mathrm{Fe}$ dose absorbed was $43.0 \%$ for the $\mathrm{B}_{2}{ }^{-}$treatment group and $52.2 \%$ for the $\mathrm{B}_{2}{ }^{+}$treatment group. The difference was significant $(P<0.01$; Table 3$)$. The 
Table 1. Effect of riboflavin deficiency on body-weights of rats at the time of dosing (test meal extrinsically labelled with ${ }^{59} \mathrm{Fe}$ ) and at the time of killing $\dagger$

(Mean values with their standard errors)

\begin{tabular}{|c|c|c|c|c|c|c|c|c|c|}
\hline \multirow{4}{*}{$\begin{array}{l}\text { Treatment } \\
\text { group }\end{array}$} & \multicolumn{8}{|c|}{ Body-wt (g) } & \\
\hline & \multirow{2}{*}{\multicolumn{3}{|c|}{$\begin{array}{l}\text { Time of dosing } \\
\text { (day } 0)\end{array}$}} & \multicolumn{5}{|c|}{ Time of killing } & \\
\hline & & & & \multicolumn{3}{|c|}{ Day 7} & \multicolumn{3}{|c|}{ Day 14} \\
\hline & $n$ & Mean & $\mathbf{S E}$ & $n$ & Mean & $\mathrm{SE}$ & $n$ & Mean & $\mathrm{SE}$ \\
\hline $\mathrm{B}_{2}^{-}$ & 35 & $160 \cdot 8$ & 1.6 & 15 & $170 \cdot 1$ & 1.6 & 20 & $168 \cdot 6^{* * *}$ & $2 \cdot 1$ \\
\hline $\mathrm{B}_{2}^{+}+$ & 35 & $162 \cdot 0$ & $1 \cdot 3$ & 15 & $178 \cdot 1$ & $1 \cdot 7$ & 20 & $181 \cdot 6$ & 1.6 \\
\hline
\end{tabular}

$\mathrm{B}_{2}{ }^{-}$, rats fed on a riboflavin-deficient diet; $\mathrm{B}_{2}{ }^{+}$, rats fed on a complete diet (control).

Mean value was significantly different from that of control animals: ${ }^{* *} P<0.001$.

$\dagger$ For details of diets and procedures, see p. 488.

Table 2. Riboflavin status of rats, measured at the time of dosing (test meal extrinsically labelled with ${ }^{59} \mathrm{Fe}$ ) and at the time of killing $\dagger$

(Mean values with their standard errors)

\begin{tabular}{|c|c|c|c|c|c|c|c|c|c|}
\hline \multirow{4}{*}{$\begin{array}{l}\text { Treatment } \\
\text { group }\end{array}$} & \multicolumn{8}{|c|}{ BGRAC } & \\
\hline & \multirow{2}{*}{\multicolumn{3}{|c|}{$\begin{array}{l}\text { Time of dosing } \\
\text { (day } 0 \text { ) }\end{array}$}} & \multicolumn{6}{|c|}{ Time of killing } \\
\hline & & & & \multicolumn{3}{|c|}{ Day 7} & \multicolumn{3}{|c|}{ Day 14} \\
\hline & $n$ & Mean & $\mathrm{SE}$ & $n$ & Mean & SE & $n$ & Mean & $\mathrm{SE}$ \\
\hline $\mathrm{B}_{2}^{-}$ & 33 & $2 \cdot 10^{* * *}$ & 0.09 & 14 & $2 \cdot 27 * * *$ & $0 \cdot 16$ & 20 & $1.89 * *$ & $0 \cdot 14$ \\
\hline $\mathrm{B}_{2}^{+}$ & 35 & $1 \cdot 32$ & $0 \cdot 06$ & 15 & $1 \cdot 19$ & 0.05 & 20 & $1 \cdot 37$ & $0 \cdot 10$ \\
\hline
\end{tabular}

$\mathbf{B}_{2}{ }^{-}$, rats fed on a riboflavin-deficient diet; $\mathbf{B}_{2}{ }^{+}$, rats fed on a complete diet (control); BGRAC, blood glutathione reductase ( $E C$ 1.6.4.2) activation coefficient.

Mean values were significantly different from those of control animals (Student's $t$ test): $* * P<0.01$, *** $P<0 \cdot 001$.

$\dagger$ For details of diets and procedures, see p. 488.

daily rate of loss of absorbed ${ }^{59} \mathrm{Fe}$, expressed as percentage daily loss, was significantly higher $(P<0.01)$ in the $\mathrm{B}_{2}^{-}$treatment group $(0.72)$ than the $\mathrm{B}_{2}^{+}$treatment group $(0.41$; Table 3).

A very rapid fall in whole-body ${ }^{59} \mathrm{Fe}$ up to day 5 reflected the excretion of unabsorbed Fe. Faecal ${ }^{59} \mathrm{Fe}$ loss of absorbed Fe was calculated as a daily percentage loss of whole-body ${ }^{59} \mathrm{Fe}$ from day 5 to day 14 . Recovery of faecal ${ }^{59} \mathrm{Fe}$ represented 104 (SE 3) \% of that lost from the body in the $\mathrm{B}_{2}{ }^{-}$treatment group and 102 (SE 3) \% in the $\mathrm{B}_{2}{ }^{+}$treatment group. All of the ${ }^{59} \mathrm{Fe}$ lost from the body over this period could, therefore, be accounted for by faecal ${ }^{59} \mathrm{Fe}$ loss.

The distribution of retained ${ }^{59} \mathrm{Fe}$ between the liver, blood and SI, is shown in Table 4. The $\mathrm{B}_{2}{ }^{-}$treatment group had a significantly higher percentage of ${ }^{59} \mathrm{Fe}$ in blood than the $\mathrm{B}_{2}{ }^{+}$ treatment group $(P<0.001)$ and, although the blood values remained constant between days 7 and 14 in the $\mathrm{B}_{2}{ }^{+}$treatment group, the ${ }^{59} \mathrm{Fe}$ (as a percentage of total body count) increased in the $\mathrm{B}_{2}{ }^{-}$treatment group $(P<0.05)$. 
Table 3. Effect of riboflavin-deficiency on ${ }^{59} \mathrm{Fe}$ absorption and daily rate of loss in groups of twenty rats killed $14 \mathrm{~d}$ after administration of a $3 \mathrm{~g}$ cooked starch-sucrose test meal containing $120 \mu \mathrm{g} \mathrm{Fe}$ and $37 \mathrm{kBq}{ }^{59} \mathrm{Fe} \dagger$

(Mean values with their standard errors)

\begin{tabular}{|c|c|c|c|c|c|}
\hline & \multirow[t]{2}{*}{ Treatment group... } & \multicolumn{2}{|c|}{$\mathrm{B}_{2}^{-}$} & \multicolumn{2}{|c|}{$\mathrm{B}_{2}^{+}$} \\
\hline & & Mean & SE & Mean & $\mathbf{S E}$ \\
\hline \multirow{2}{*}{$\cdots$} & ${ }^{59} \mathrm{Fe}$ absorption $\ddagger(\%)$ & $43 \cdot 0 * *$ & $2 \cdot 1$ & $52 \cdot 2$ & 1.8 \\
\hline & Rate of ${ }^{59} \mathrm{Fe}$ loss $/ \mathrm{d} \ddagger(\%)$ & $0.72 * *$ & $0-08$ & 0.41 & 0.06 \\
\hline
\end{tabular}

$\mathrm{B}_{\mathrm{a}}{ }^{\cdots}$, rats fed on a riboflavin-deficient diet; $\mathrm{B}_{2}{ }^{+}$, rats fed on a complete diet (control).

Mean value was significantly different from that of control animals: ${ }^{* *} P<0.01$.

$\dagger$ For details of diets and procedures, see p. 488.

$\ddagger$ Calculated from regression analysis, see p. 488 .

Table 4. Effect of riboflavin deficiency on tissue distribution of absorbed ${ }^{59} \mathrm{Fe}$ (percentage of whole-body count) from a test meal extrinsically labelled with ${ }^{59} \mathrm{Fe}$, at time of killing*

(Mean values with their standard errors)

\begin{tabular}{|c|c|c|c|c|c|c|c|c|c|c|}
\hline \multirow{3}{*}{$\begin{array}{l}\text { Treatment group... } \\
\text { No. of rats... }\end{array}$} & \multicolumn{4}{|c|}{ Day 7} & \multicolumn{4}{|c|}{ Day 14} & & \\
\hline & \multicolumn{2}{|c|}{$\begin{array}{c}\mathrm{B}_{2}^{-} \\
15\end{array}$} & \multicolumn{2}{|c|}{$\begin{array}{c}\mathrm{B}_{2}^{+} \\
15\end{array}$} & \multicolumn{2}{|c|}{$\begin{array}{c}\mathrm{B}_{2}^{-} \\
20\end{array}$} & \multicolumn{2}{|c|}{$\begin{array}{c}\mathrm{B}_{2}^{+} \\
20\end{array}$} & \multicolumn{2}{|c|}{$\begin{array}{l}\text { Statistical significance } \\
\text { of effect }(P) \dagger \text { of: }\end{array}$} \\
\hline & Mean & SE & Mean & $\mathrm{SE}$ & Mean & $\mathrm{SE}$ & Mean & $\mathrm{SE}$ & Diet & Time \\
\hline Liver & 31.53 & 1.90 & $35 \cdot 90$ & $2 \cdot 11$ & $27 \cdot 11$ & $1 \cdot 40$ & $29 \cdot 41$ & 1.00 & & $<0.01$ \\
\hline Blood $(/ \mathrm{ml})$ & 4.91 & $0-17$ & $4 \cdot 64$ & 0.23 & 5.91 & 0.16 & $4 \cdot 60$ & 0.24 & $<0.001$ & $<0.05$ \\
\hline Duodenum & 0.280 & 0.014 & 0.256 & $0 \cdot 009$ & 0.277 & 0.010 & 0.241 & 0.008 & $<0.01$ & \\
\hline Jejunum & 0.729 & $0 \cdot 034$ & 0.657 & 0.033 & 0.647 & 0.021 & $0 \cdot 494$ & 0.023 & $<0.001$ & $<0.001$ \\
\hline Ileum & $1 \cdot 103$ & 0.072 & 0.839 & 0.043 & 0.973 & 0.032 & 0.749 & 0.059 & $<0.001$ & $<0.05$ \\
\hline Total SI & 2.089 & $0 \cdot 112$ & 1.752 & 0.081 & 1.897 & 0.052 & 1.484 & 0.079 & $<0.001$ & $<0.01$ \\
\hline
\end{tabular}

SI, small intestine.

* For details of diets and procedures, see p. 488.

$\uparrow$ Values were analysed by a 2 -way analysis of variance.

The $\mathrm{B}_{2}{ }^{-}$treatment group showed a greater proportion of retained ${ }^{59} \mathrm{Fe}$ in each section of the SI than in the $\mathrm{B}_{2}^{+}$control animals. With increasing time interval after ${ }^{59} \mathrm{Fe}$ dose there was a decrease in the proportion of body ${ }^{59} \mathrm{Fe}$ in the jejunum and ileum which was not seen in the duodenum. Similarly, when values for each section of the SI were summed for individual rats it was evident that riboflavin deficiency was associated with a greater retention of ${ }^{59} \mathrm{Fe}$. The proportion of ${ }^{59} \mathrm{Fe}$ found in the SI decreased with the time interval after dosing. In order to investigate the effects of isotope dilution on the distribution of absorbed ${ }^{59} \mathrm{Fe}$ the specific activity of ${ }^{59} \mathrm{Fe}$ was calculated for the liver and SI. Table 5 shows the specific activity of ${ }^{59} \mathrm{Fe}$ to be the same in the liver and ileum of the two experimental groups and lower in the duodenum, jejunum and total SI of the $\mathrm{B}_{2}{ }^{-}$treatment group than the $\mathrm{B}_{2}{ }^{+}$control group. Though the proportion of ${ }^{59} \mathrm{Fe}$ retained at day 14 was higher per $\mathrm{ml}$ of circulating blood in the $\mathrm{B}_{2}{ }^{-}$treatment group (Table 4), this was offset by a lower wholebody ${ }^{59} \mathrm{Fe}$ retention (Table 3 ), such that the absolute amount of ${ }^{59} \mathrm{Fe} / \mathrm{ml}$ of circulating blood was not significantly different between groups.

Preferential retention of body $\mathrm{Fe}$ in the SI in riboflavin deficiency is also evident from 
Table 5. Effect of riboflavin deficiency on specific activity $(\mathrm{Bq} / \mu \mathrm{g})$ absorbed ${ }^{59} \mathrm{Fe}$ in small intestine and liver at time of killing*

(Mean values with their standard errors)

\begin{tabular}{|c|c|c|c|c|c|c|c|c|c|c|}
\hline \multirow{3}{*}{$\begin{array}{l}\text { Treatment group } \ldots \\
\text { No. of rats ... }\end{array}$} & \multicolumn{4}{|c|}{ Day 7} & \multicolumn{4}{|c|}{ Day 14} & & \\
\hline & \multicolumn{2}{|c|}{$\mathrm{B}_{2}^{-}$} & \multicolumn{2}{|c|}{$\begin{array}{c}\mathrm{B}_{2}^{+} \\
15\end{array}$} & \multicolumn{2}{|c|}{$\begin{array}{c}\mathrm{B}_{2}^{-} \\
20\end{array}$} & \multicolumn{2}{|c|}{$\begin{array}{c}\mathrm{B}_{2}^{+} \\
20\end{array}$} & \multicolumn{2}{|c|}{$\begin{array}{c}\text { Statistical significance } \\
\text { of effect }(P)^{\dagger} \text { of: }\end{array}$} \\
\hline & Mean & $\mathrm{SE}$ & Mean & SE & Mean & $\mathrm{SE}$ & Mean & $\mathrm{SE}$ & Dict & Time \\
\hline Liver & $3 \cdot 90$ & 0.53 & $4 \cdot 43$ & $0 \cdot 37$ & 3.04 & $0 \cdot 30$ & $3 \cdot 71$ & $0 \cdot 25$ & & $<0.05$ \\
\hline Duodenum & $3 \cdot 88$ & 0.24 & $4 \cdot 14$ & $0 \cdot 14$ & $3 \cdot 24$ & $0 \cdot 20$ & 3.91 & 0.13 & $<0.01$ & $<0.05$ \\
\hline Jejunum & 3.27 & 0.29 & 4.08 & 020 & $3 \cdot 44$ & $0 \cdot 19$ & 3.89 & $0 \cdot 13$ & $<0.01$ & \\
\hline Ileum & $2 \cdot 04$ & $0 \cdot 13$ & $2 \cdot 13$ & 0.11 & $2 \cdot 08$ & 0.21 & $2 \cdot 56$ & $0 \cdot 33$ & & \\
\hline Total SI & $2 \cdot 45$ & $0 \cdot 16$ & $2 \cdot 82$ & $0 \cdot 13$ & $2 \cdot 50$ & $0 \cdot 19$ & $3 \cdot 01$ & $0 \cdot 19$ & $<0.05$ & \\
\hline
\end{tabular}

SI, small intestine

* For details of diets and procedures, see p. 488.

$\uparrow$ Values were analysed by a 2 -way analysis of variance.

Table 6. Effect of riboflavin deficiency on tissue distribution of body iron ( $\mu \mathrm{g} / \mathrm{g} d r y$ weight) and total liver iron stores $(\mu g)^{*}$

(Mean values with their standard errors)

\begin{tabular}{|c|c|c|c|c|c|c|c|c|c|c|}
\hline \multirow{3}{*}{$\begin{array}{l}\text { Treatment group... } \\
\text { No. of rats... }\end{array}$} & \multicolumn{4}{|c|}{ Day 7} & \multicolumn{4}{|c|}{ Day 14} & & \\
\hline & \multicolumn{2}{|c|}{$\begin{array}{l}\mathrm{B}_{2}^{-} \\
15\end{array}$} & \multicolumn{2}{|c|}{$\begin{array}{c}\mathrm{B}_{2}^{+} \\
15\end{array}$} & \multicolumn{2}{|c|}{$\begin{array}{c}\mathrm{B}_{2}^{-} \\
20\end{array}$} & \multicolumn{2}{|c|}{$\begin{array}{c}\mathrm{B}_{2}^{+} \\
20\end{array}$} & \multicolumn{2}{|c|}{$\begin{array}{l}\text { Statistical significance } \\
\quad \text { of effect }(P) \dagger \text { of: }\end{array}$} \\
\hline & Mean & SE & Mean & SE & Mean & $\mathrm{SE}$ & Mean & $\mathrm{SE}$ & Diet & Time \\
\hline Liver: $\mu \mathrm{g}$ total & 1258 & $48 \cdot 3$ & 1399 & $59 \cdot 4$ & 1373 & $44 \cdot 5$ & 1489 & $27 \cdot 3$ & $<0.01$ & $<0.05$ \\
\hline$\mu \mathrm{g} / \mathrm{g}$ & $752 \cdot 1$ & $21 \cdot 2$ & $797 \cdot 0$ & $34 \cdot 8$ & $803 \cdot 0$ & $34 \cdot 9$ & $809 \cdot 7$ & $15 \cdot 9$ & & \\
\hline Duodenum $(u \mathrm{~g} / \mathrm{g})$ & $54 \cdot 3$ & $1 \cdot 5$ & $54 \cdot 0$ & $1 \cdot 8$ & 57.5 & $2 \cdot 7$ & $54 \cdot 4$ & $1 \cdot 4$ & & \\
\hline Jejunum $(\mu \mathrm{g} / \mathrm{g})$ & $75 \cdot 3$ & $8 \cdot 5$ & $55 \cdot 1$ & $5 \cdot 0$ & $52 \cdot 7$ & $2 \cdot 1$ & $43 \cdot 4$ & $1 \cdot 3$ & $<0.01$ & $<0.001$ \\
\hline Ileum $(\mu \mathrm{g} / \mathrm{g})$ & $116 \cdot 0$ & $6 \cdot 5$ & 1032 & $6 \cdot 2$ & $109 \cdot 2$ & $5 \cdot 2$ & $82 \cdot 9$ & $5 \cdot 5$ & $<0.001$ & $<0.05$ \\
\hline Total SI $(\mu \mathrm{g} / \mathrm{g})$ & $92 \cdot 5$ & $4 \cdot 4$ & $77 \cdot 7$ & $3 \cdot 9$ & $80 \cdot 2$ & 2.9 & $64 \cdot 0$ & $3 \cdot 0$ & $<0.00 \mathrm{I}$ & $<0.001$ \\
\hline
\end{tabular}

SI, small intestine

* For details of diets and procedures, see p. 488.

$\dagger$ Values were analysed by 2 -way analysis of variance

Table 6, which shows the concentration of Fe in different parts of the SI at time of kill. $\mathrm{B}_{2}^{-}-$ treated rats clearly have significantly lower total liver $\mathrm{Fe}$ stores than $\mathrm{B}_{2}{ }^{+}$-treated control rats.

\section{Crypt cell study}

Riboflavin-deficiency was evident in the $\mathrm{B}_{2}{ }^{-}$treatment group, which had a mean BGRAC of 1.91 (SE 0.09) when killed. This value was significantly higher than that of the control group $(1 \cdot 16($ SE $0 \cdot 07))$.

The effects of riboflavin deficiency on crypt morphometry and mitotic activity are shown in Table 7. There was no effect on body-weights at the time of kill, or SI lengths. However, the $\mathrm{B}_{2}^{--}$-treated animals showed a significant proliferative response of the duodenal crypts; this was characterized by an increase in crypt depth and width and an increase in the mitotic index (metaphase arrest/crypt). The magnitude of the effect is clearly seen in Fig. 1. 
Table 7. Effect of riboflavin deficiency on body-weights, and characteristics of the upper small intestine of rats $\dagger$

(Mean values with their standard errors for six rats/group)

\begin{tabular}{|c|c|c|c|c|}
\hline \multirow[t]{2}{*}{ Treatment group ... } & \multicolumn{2}{|l|}{$\mathrm{B}_{2}^{-}$} & \multicolumn{2}{|c|}{$\mathbf{B}_{2}^{+}$} \\
\hline & Mean & $\mathrm{SE}$ & Mean & $\mathrm{SE}$ \\
\hline Body-wt (g) & 123 & $4 \cdot 6$ & 125 & $3 \cdot 7$ \\
\hline Small intestine length $(\mathrm{mm})$ & 765 & 27 & 767 & 20 \\
\hline Crypt depth $(\mu \mathrm{m})$ & $267 * * *$ & $3 \cdot 2$ & 193 & $4 \cdot 0$ \\
\hline Crypt width $(\mu \mathrm{m})$ & $62 * *$ & $2 \cdot 6$ & 54 & $1 \cdot 2$ \\
\hline Mitotic index + & $48 * * *$ & 1.5 & 26 & $1 \cdot 0$ \\
\hline
\end{tabular}

$\mathrm{B}_{2}{ }^{-}$, rats fed on a riboflavin-deficient diet; $\mathrm{B}_{2}{ }^{+}$, rats fed on a complete diet (control).

Mean values were significantly different from those of control animals: ${ }^{* *} P<0 \cdot 01,{ }^{* * *} P<0 \cdot 001$.

$\dagger$ For details of diets and procedures, see pp. 488-489.

$\$$ No. of cells in metaphase arrest/crypt.

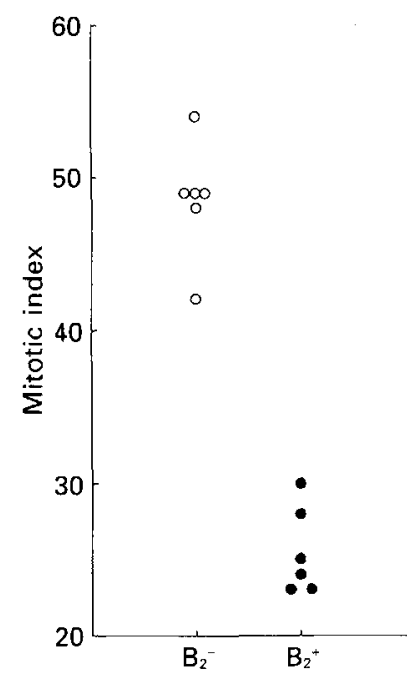

Fig. 1. Mitotic index in upper small intestinal epithelium of six riboflavin-depleted $\left(\mathrm{B}_{2}{ }^{-}\right.$-treated) animals and six control $\left(\mathrm{B}_{2}{ }^{+}\right.$-treated) animals. For details of treatments, see p. 488 . Mitotic index is the mean number of metaphase arrests/ten crypts per animal $2.5 \mathrm{~h}$ after an intraperitoneal injection of $1.5 \mathrm{mg}$ vincristine.

\section{DISCUSSION}

The purpose of the study described here was threefold: (1) to confirm the effect of riboflavin-deficiency on $\mathrm{Fe}$ absorption and loss which we observed in a previous experiment, (2) to clarify the route of the $\mathrm{Fe}$ loss, (3) to investigate the effect of riboflavin deficiency on crypt cell proliferation in the small intestine.

\section{Fe utilization}

Riboflavin deficiency was clearly associated with an impaired $\mathrm{Fe}$ absorption, an increased rate of loss of absorbed Fe and lower liver Fe stores. Having absorbed a smaller percentage of the ${ }^{59} \mathrm{Fe}$ dose the riboflavin-deficient $\left(\mathrm{B}_{2}{ }^{-}\right.$-treated) rats distributed this $\mathrm{Fe}$ differently from the $\mathrm{B}_{2}{ }^{+}$-treated controls. Thus, the blood contained a greater proportion of the 
absorbed $\mathrm{Fe}$, presumably in response to the high requirements of the erythroid marrow. A refinement of the experimental technique, compared with the earlier study, was to give both groups of animals the same quantity of diet after the test meal. This was in order to ensure that dietary $\mathrm{Fe}$ intakes were the same in the two groups, and thereby to control for any influence that dietary Fe intake might have on whole-body Fe turnover. The effect of this was that $\mathrm{B}_{2}{ }^{-}$-treated animals, with a lower efficiency of food utilization, were slightly lighter than $\mathrm{B}_{2}{ }^{+}$-treated controls at day 14 . This should not have influenced the distribution of the absorbed Fe.

The magnitude of the difference in rate of Fe loss was not as great as previously observed (Powers et al. 1988) but was nevertheless highly significant. The fact that the daily loss of absorbed ${ }^{59} \mathrm{Fe}$ could all be accounted for in faecal output confirms our previous suggestion that the loss occurred entirely through the gastrointestinal tract. However, the precise route of the post-absorption Fe loss, and the mechanism for the enhanced loss in riboflavin deficiency, requires careful consideration of the findings. Riboflavin deficiency was associated with an increased uptake of absorbed ${ }^{59} \mathrm{Fe}$ by the SI as was evident from the distribution values $14 \mathrm{~d}$ after the ${ }^{59} \mathrm{Fe}$ dose. There was no evidence that differences in specific activity of ${ }^{59} \mathrm{Fe}$ between the two experimental groups could have accounted for this observation. In fact the specific activity of ${ }^{59} \mathrm{Fe}$ in the SI was lower in the $\mathrm{B}_{2}{ }^{-}$treatment group than the control group. This is to be expected in the light of the observed reduction in ${ }^{59} \mathrm{Fe}$ absorption and increase in the concentration of $\mathrm{Fe}$ in the $\mathrm{SI}$ of the $\mathrm{B}_{2}^{-}$treatment group.

The increased concentration of $\mathrm{Fe}$ in the $\mathrm{SI}$ of the $\mathrm{B}_{2}{ }^{-}$-treated animals might contribute to an elevated daily loss of Fe during the normal course of mucosal cell turnover.

Post-absorption Fe excretion has been observed by other groups of workers in humans (Green et al. 1968; Björn-Rasmussen et al. 1980; Johnson, 1984). A number of hypotheses have been put forward to explain the observation but none has been thoroughly investigated and the observation has generally received little recognition. The postabsorption loss of Fe observed in our study cannot be due simply to the exfoliation of mucosal cells carrying ${ }^{59} \mathrm{Fe}$ that never passed into the blood as it continued long after the normal lifespan of the mucosal cell. On the other hand, ${ }^{59} \mathrm{Fe}$ which was completely absorbed could have been made available in the blood for the synthesis of Fe-containing compounds within newly synthesized mucosal cells and subsequently lost by exfoliation (Linder \& Munro, 1977). There is some evidence in the literature that $\mathrm{Fe}$ may be lost by a serosal-to-mucosal transfer of $\mathrm{Fe}$, independent of mucosal cell turnover, possibly by excretion through goblet cells (Guy \& Schachter, 1975; Refsum \& Schreiner, 1980; Schreiner \& Refsum, 1983). Finally, it cannot be ruled out that there is some capacity for enteroenteric recirculation, with the Fe being released from mucosal cells as they slough off being reabsorbed lower in the gut. If this were a significant component of the Fe movement in our experiment, it might be expected that the duodenum would actually be depleted of Fe more rapidly than the jejunum and ileum, which was not the case.

\section{Crypt cell proliferation}

Riboflavin deficiency, of a severity similar to that associated with an increased daily rate of loss of $\mathrm{Fe}$, was associated with an enhanced proliferative response of the mucosal epithelia of the upper SI. It remains to be determined whether this is associated with an accelerated villus enterocyte loss and an influx of immature enterocytes. An accelerated enterocyte turnover would be expected to increase the daily rate of loss of Fe from the body. To our knowledge, there is only one other report in the literature of an effect of riboflavin deficiency on mucosal cell turnover. Miyaji \& Hala (1965) reported that riboflavin deficiency in the mouse was associated with an increased turnover rate of the mucosal epithelial cells of the SI. 
The deleterious effect of riboflavin deficiency on Fe absorption may be a direct result of the mechanism leading to enhanced $\mathrm{Fe}$ loss but as there is no published information describing a relationship between mucosal cell turnover rate, hypertrophy, and $\mathrm{Fe}$ absorption, this is merely speculation. There are as yet no grounds on which to reject the hypothesis that the impaired $\mathrm{Fe}$ absorption seen in riboflavin deficiency is due to a reduced activity of a flavin-dependent oxidoreductase in the mucosal cells of the SI, as described in an earlier study (Powers, 1986).

In conclusion, riboflavin deficiency leads to impaired $\mathrm{Fe}$ absorption and an increased $\mathrm{Fe}$ loss from the gastrointestinal tract. An increased turnover of the mucosal epithelia of the SI and preferential accumulation of body Fe by the SI could both be factors contributing to the disturbed Fe metabolism. The precise mechanisms remain to be elucidated.

The authors would like to thank Ms Anne Flack and Mrs Jacqui Cooke for skilled care of the animals.

\section{REFERENCES}

Adelekan, D. A. \& Thurnham, D. I. (1986) A longitudinal study of the effect of riboflavin status on aspects of iron storage in the liver of growing rats. British Journal of Nutrition 56, 171-179.

Björn-Rasmussen, E., Carneskog, J. \& Cederblad, A. (1980). Losses of ingested iron temporarily retained in the gastrointestinal tract. Scandinavian Journal of Haematology 25, 124-126.

Buzina, R., Jusic, M., Milanovic, N., Sapunar, J. \& Brubacher, G. (1979). The effects of riboflavin administration on iron metabolism parameters in a school-going population. International Journal of Vitamin and Nutrition Research 49, 136-143.

Duerden, J. M. \& Bates, C. J. (1985). Effect of riboflavin deficiency on reproductive performance and on biochemical indices of riboflavin status in the rat. British Journal of Nutrition 53, 97-105.

Fairweather-Tait, S. J., Swindell, T. E. \& Wright, A. J. A. (1985). Further studies in rats on the influence of previous iron intake on the estimation of bioavailability of iron. British Journal of Nutrition 54, 79-86.

Fairweather-Tait, S. J. \& Wright, A. J. A. (1984). The influence of previous iron intake on the estimation of bioavailability of Fe from a test meal given to rats. British Journal of Nutrition 51, 185-191.

Green, R., Charlton, R., Seftel, H., Bothwell, T., Mayet, F., Adams, B., Finch, C. \& Layrisse, M. (1968). Body iron excretion in man. American Journal of Medicine 45, 336-353.

Guy, M. J. \& Schachter, D. (1975). Active transport of iron to mucosal surface of rat jejunum. American Journal of Physiology 229, 790-796.

Johnson, P. E. (1984). Stable isotopes of iron, zinc and copper used to study mineral absorption in humans. In Stable Isotopes in Nutrition, ACS Symposium Series no. 258, pp. 139-155 [J. R. Turnlund and P. E. Johnson, editors]. Washington DC: American Chemical Society.

Linder, M. \& Munro, H. M. (1977). The mechanism of iron absorption and its regulation. Federation Proceedings 36, 2017-2023.

Miyaji, K. \& Hala, Y. (1965). Effect of riboflavin or iron deficiency on the cell renewal rate of intestinal mucosa. Vitamins 31, 185-191.

Powers, H. J. (1986). Investigation into the relative effects of riboflavin deprivation on iron economy in the weaning rat and the adult. Annals of Nutrition and Metabolism 30, 308-315.

Powers, H. J. (1987). A study of maternofetal iron transfer in the riboflavin-deficient rat. Journal of Nutrition 117, $852-856$

Powers, H. J., Bates, C. J. \& Duerden, J. M. (1983a). Effects of riboflavin deficiency in rats on some aspects of iron metabolism. International Journal of Vitamin and Nutrition Research 53, 37I-376.

Powers, H. J., Bates, C. J., Prentice, A. M., Lamb, W. H., Jepson, M. \& Bowman, H. (1983b). The relative effectiveness of iron and iron with riboflavin in correcting a microcytic anaemia in men and children in rural Gambia. Human Nutrition: Clinical Nutrition 37C, 413 425.

Powers, H. J., Wright, A. J. A. \& Fairweather-Tait, S. J. (1988). The effect of riboflavin deficiency in rats on the absorption and distribution of iron. British Journal of Nutrition 59, 381-387.

Refsum, S. B. \& Schreiner, B. (1980). Iron excretion from the goblet cells of the small intestine in man. Journal of Gastroenterology 15, 1013-1020.

Schreiner, B. \& Refsum, S. B. (1983). Letter. Lancet i, 1385.

Sirivech, S., Driskeli, J. \& Frieden, E. (1977). NADH : FMN oxidoreductase activity and iron content of rat organs from riboflavin-deficient and iron-deficient rats. Journal of Nutrition 107, 739-745.

Ulvik, R. J. \& Romslo, I. (1981). Reduction of exogenous FMN by isolated rat liver mitochondria. Significance to the mobilization of iron from ferritin. Biochimica et Biophysica Acta 635, 457-469. 
Wright, N. A. \& Appleton, D. R. (1980). The metaphase arrest technique: a critical review. Cell Tissue Kinetics 13, 643-663.

Wright, N. A. \& Irwin, M. (1982). The kinetics of villus cell populations in the mouse small intestine. Cell Tissue Kinetics 15, 596-609.

Zaman, S. \& Verwilghen, R. L. (1977). Effect of riboflavin deficiency on activity of NADH-FMN oxidoreductase (ferriductase) and iron content of rat liver. Biochemical Society Transactions 5, 306. 